\title{
Kolagen dari Limbah Tulang Ayam (Gallus gallus domesticus) terhadap Aktivitas Anti Aging secara In Vitro
}

\author{
Eka Budiarti ${ }^{\mathrm{a}}$, Perlambang Budiartia ${ }^{\mathrm{a}}$, Manggar Arum Aristri ${ }^{\mathrm{a}}$, Irmanida \\ Batubara $^{\mathbf{a}, \mathbf{b}_{*}}$ \\ ${ }^{a}$ Departemen Kimia, FMIPA, Institut Pertanian Bogor, Gedung Departemen Kimia Wing 2 Level 1, Jalan \\ Tanjung No. 3 Kampus IPB Dramaga, Bogor 16680 telp. (0251) 8624567 \\ ${ }^{b}$ Pusat Studi Biofarmaka Tropika, LPPM IPB, Jalan Taman Kencana No 3 Bogor 16128 telp (0251) 8373561 \\ * Corresponding author \\ E-mail: imebatubara@apps.ipb.ac.id
}

DOI: 10.20961/alchemy.15.1.23046.44-56

Received 19 August 2018, Accepted 30 November 2018, Published 01 March 2019

\begin{abstract}
ABSTRAK
Limbah tulang ayam meningkat seiring dengan peningkatan konsumsi ayam. Namun, belum banyak penelitian yang memanfaatkan limbah tulang sebagai sumber kolagen. Penelitian ini bertujuan mengetahui pengaruh ukuran kolagen terhadap aktivitas anti aging berupa aktivitas antioksidan, antiglikasi, dan inhibitor tirosinase secara in vitro dan mendapatkan teknik isolasi kolagen anti aging optimum dari tulang ayam. Isolasi kolagen dilakukan dengan variasi konsentrasi $\mathrm{NaOH}$, yaitu $0,05 \mathrm{M} ; 0,10 \mathrm{M}$; dan 0,20 $\mathrm{M}$, dilanjutkan dengan perendaman menggunakan asam asetat $1 \mathrm{M}$. Kolagen yang diisolasi dengan $\mathrm{NaOH} 0,10 \mathrm{M}$ merupakan kolagen dengan ukuran partikel, rendemen, dan antiglikasi terbesar (berturut-turut 2,34 $\mu \mathrm{m}$, $12,59 \%, 61,06 \%$ ) dan memiliki spektrum inframerah yang paling sesuai dengan kolagen standar. Kolagen ini kemudian diaduk dengan kecepatan 1000 rpm selama 6 dan 8 jam untuk pengecilan ukuran. Kolagen dengan pengadukan 6 jam mempunyai ukuran partikel lebih kecil $(1,34 \mu \mathrm{m})$ dibandingkan dengan pengadukan 8 jam $(1,80 \mu \mathrm{m})$. Kolagen dengan ukuran $1,34 \mu \mathrm{m}$ menunjukkan aktivitas terbaik yaitu aktivitas antioksidan terhadap 2,2-difenil-1-pikrilhidrazil (DPPH) sebesar 24,70\% dan inhibitor tirosinase sebesar 26,77\%. Berdasarkan aktivitas antioksidan, antiglikasi, dan antitirosinase, kolagen dengan perendaman $\mathrm{NaOH} 0,10 \mathrm{M}$ dan pengadukan selama 6 jam memiliki sifat anti aging yang paling baik.
\end{abstract}

Kata kunci: antiglikasi, antioksidan, inhibitor tirosinase, kolagen, ukuran partikel.

\section{ABSTRACT}

In Vitro Anti-Aging Activity of Chicken (Gallus gallus domesticus) Bone Waste Collagen. Chicken bone waste increases with increasing chicken compsumtion. However, study on utilizing chicken bone for collagen source has not been widely explored. This study aims to determine the effect of collagen size on their anti aging activity, and to obtain the optimum condition to produce the chicken (Gallus gallus domesticus) collagen in the high yield and the best activity. Collagen isolation was carried out in various $\mathrm{NaOH}$ concentrations of $0.05 \mathrm{M}, 0.10 \mathrm{M}$, and $0.20 \mathrm{M}$, followed by the maceration on acetic acid $1 \mathrm{M}$. The isolation in $\mathrm{NaOH} 0.10 \mathrm{M}$ produced the collagen with particle size of $2.34 \mu \mathrm{m}$ in yield of $12.59 \%$ and antiglycation of $61.06 \%$. The revealed infrared spectrum of the isolated collagen is almost the same with the spectrum of the standart collagen. The collagen in $2.34 \mu \mathrm{m}$ was further stirred at a $1000 \mathrm{rpm}$ for 6 and 8 hours to reduce the size. Collagen stirred in 6 hours has a smaller particle size $(1.34 \mu \mathrm{m})$ compared with that of stirred in 8 hours which has a particle size of $1.80 \mu \mathrm{m}$. The collagen with size of $1.34 \mu \mathrm{m}$ showed the best activity, which revealed the antioxidant activity of 2,2-diphenyl-1-picrylhydrazyl (DPPH) of $24.70 \%$ and 
tyrosinase inhibitors of $26.77 \%$. Based on antioxidant activity, anti-glycation, and anti-tyrosinase, the collagen which was isolated in $0.10 \mathrm{M} \mathrm{NaOH}$ and was stirred in 6 hours has the best anti-aging property.

Keywords: anti-glycation, antioxidant, collagen, particle size, tyrosinase inhibitor

\section{PENDAHULUAN}

Penuaan merupakan proses yang pasti terjadi, namun penuaan dini merupakan hal yang tidak diharapkan. Penuaan pada kulit manusia ditandai dengan penipisan kulit, kulit kering, keriput, dan warna yang tidak merata (Farage et al., 2016). Hal ini disebabkan oleh reaksi enzimatik seperti enzim tirosinase, yaitu enzim yang terlibat dalam reaksi pembentukan melanin, maupun non enzimatik yang terjadi di dalam tubuh melibatkan reaksi glikasi dan reaksi oksidasi. Glikasi merupakan reaksi antara gula pereduksi dengan gugus amina pada protein, lemak, dan asam nukleat melalui serangkaian reaksi membentuk basa Schiff dan produk Amadori menghasilkan AGEs (advanced glycation end-products). Reaksi tersebut dikenal dengan reaksi Maillard (Nagai et al., 2001). Antioksidan dapat mengurangi pembentukan salah satu produk AGE dari jalur oksidatif. Selain itu, secara alamiah sedikitnya $1 \%$ kolagen di dalam tubuh manusia hilang setiap tahunnya dan pada usia 40 tahun manusia tidak memproduksi kolagen lagi sehingga kolagen yang hilang mencapai 35-40 \%. Oleh karena itu diperlukan kolagen dari luar tubuh yang memiliki aktivitas anti aging untuk mencegah penuaan berlangsung lebih cepat.

Ayam merupakan salah satu jenis unggas yang mengandung bahan bermanfaat, seperti kolagen yang banyak terdapat pada kulit dan tulang rawan. Kolagen merupakan salah satu jenis protein struktural yang tersusun dari beberapa asam amino. Kolagen selain dapat diaplikasikan pada produk kesehatan, juga banyak digunakan untuk kosmetika, di antaranya untuk meningkatkan kelembaban kulit dan mencegah penuaan dini (Silva et al., 2014). Di Indonesia, kebutuhan kolagen umumnya masih diperoleh dari impor, sehingga diperlukan usaha untuk dapat memproduksi sendiri kolagen.

Penelitian ini memanfaatkan limbah tulang ayam sebagai bahan penghasil kolagen yang dapat menghambat terjadinya tanda penuaan di kulit. Material berukuran lebih kecil lebih mudah memasuki bagian dalam kulit dibandingkan dengan material berukuran besar (Hoet et al., 2004). Penelitian ini bertujuan mengetahui pengaruh ukuran kolagen terhadap aktivitas anti aging berupa uji aktivitas antioksidan, antiglikasi, dan inhibitor tirosinase secara in vitro dan mendapatkan teknik isolasi kolagen anti aging optimum dari tulang ayam. 


\section{METODE PENELITIAN}

Penelitian ini menggunakan alat-alat kaca, freeze-dryer, spektrofotometer, neraca analitik, dan cawan alumunium, alat yang digunakan untuk mengukur ukuran partikel (Particle Size Analyzer/PSA, Delsa Nano C, Beckman Coulter), alat untuk mengidentifikasi gugus fungsi (Fourier Tranform Infrared/FTIR, Tensor 37, Bruker), alat untuk menentukan absorbansi pada uji aktivitas antioksidan (Enzyme-linked immunosorbent assay/ELISA Reader), dan alat untuk menentukan intensitas fluoresensi pada uji aktivitas antiglikasi (Fluorometer, FLUOstar Omega fluorometer (BMG Labtech, USA)). Bahan yang digunakan dalam penelitian ini adalah tulang ayam yang didapatkan dari Pasar Dramaga, $\mathrm{NaOH}, \mathrm{CH}_{3} \mathrm{COOH}$, akuades, etanol, 2,2-difenil-1-pikrilhidrazil (DPPH), fruktosa, sukrosa, BSA (Bovine Serum Albumin), L-3,4-dihidroksifenilalanin (LDOPA), L-Tirosin, dan buffer $\mathrm{pH}$ 7,4. Semua bahan yang digunakan berasal dari Sigma Aldrich.

\section{Preparasi Sampel}

Preparasi sampel dilakukan dengan cara membersihkan tulang ayam (Gallus gallus domesticus), kemudian tulang ayam tersebut direbus hingga mendidih. Setelah mendidih, tulang ayam didinginkan dan dipisahkan dari daging yang masih menempel. Tulang yang sudah bersih selanjutnya dihancurkan agar memudahkan dalam proses pengeringan. Tulang dikeringkan menggunakan Cabinet Dryer selama 6 jam pada suhu $40{ }^{\circ} \mathrm{C}$ hingga didapatkan sampel kering melalui penentuan kadar air. Sampel kering selanjutnya diserbukkan hingga didapatkan serbuk ukuran 60-100 mesh.

\section{Penentuan Kadar Air, Kadar Protein, dan Kadar Lemak}

Penentuan kadar air sampel mengacu pada AOAC (2012) menggunakan metode pemanasan langsung. Penentuan kadar protein menggunakan metode Kjeldahl dan kadar lemak menggunakan metode Soxhlet yang dilakukan mengacu pada SNI 01-2891-1992.

\section{Isolasi Kolagen}

Isolasi kolagen dari tulang ayam dalam penelitian ini diawali dengan perendaman sampel kering tulang dengan menggunakan 3 variasi konsentrasi $\mathrm{NaOH}$, yaitu $0,05 \mathrm{M}$; 0,10 M; dan 0,20 M dengan rasio 1:10 (b/v) selama 48 jam. Tulang kemudian direndam dalam larutan $\mathrm{CH}_{3} \mathrm{COOH} 1 \mathrm{M}$ dengan rasio 1:10 (b/v) selama 24 jam. Filtrat yang diperoleh selanjutnya disaring menggunakan kertas saring Whatman No.1. Kolagen yang diperoleh kemudian dikeringkan dengan freeze-dryer. 


\section{Pengecilan Ukuran Kolagen}

Kolagen yang diperoleh dari perlakuan perendaman larutan $\mathrm{NaOH}$ terbaik dilarutkan dalam akuades dengan rasio 1:2 (v/v) dan dilakukan pengubahan ukuran dengan bantuan pengaduk magnet pada kecepatan 1000 rpm dengan variasi waktu 6 dan 8 jam. Hasilnya kemudian diuji ukuran partikelnya menggunakan PSA kemudian diuji aktivitas antioksidan dengan metode DPPH (2,2-difenil-1-pikrilhidrazil), antiglikasi, dan inhibitor tirosinase.

\section{Penentuan Aktivitas Antioksidan}

Penentuan aktivitas antioksidan dilakukan dengan menggunakan metode DPPH mengacu pada Batubara et al. (2009). Sampel dengan konsentrasi tertentu selanjutnya diambil $100 \mu \mathrm{L}$, dimasukkan ke dalam microplate 96 well dan ditambahkan dengan DPPH 0,3 $\mathrm{mM}$ sebanyak $100 \mu \mathrm{L}$, kemudian diinkubasi selama 30 menit dalam ruang gelap. Absorbansi sampel diukur dengan menggunakan ELISA reader pada panjang gelombang $517 \mathrm{~nm}$. Aktivitas antioksidan dihitung dengan persamaan 1 sebagai berikut:

$$
\text { Inhibisi }(\%)=\frac{\mathrm{A} 0-\mathrm{A} 1}{\mathrm{~A} 0} \times 100 \%
$$

$$
\begin{array}{ll}
\text { Keterangan : } & \mathrm{A}_{0}=\text { Absorbansi dari blanko } \\
& \mathrm{A}_{1}=\text { Absorbansi dari standar atau sampel }
\end{array}
$$

\section{Penentuan Aktivitas Antiglikasi}

Metode antiglikasi mengacu pada Povichit (2010) dengan menyiapkan larutan uji seperti pada Tabel 1. Seluruh larutan uji tersebut diinkubasi pada suhu $60{ }^{\circ} \mathrm{C}$ selama 40 jam. Setelah inkubasi, larutan kemudian dipipet sebanyak $100 \mu \mathrm{L}$ ke dalam 96-well plate. Jumlah relatif BSA yang terglikasi diukur menggunakan fluorometer pada panjang gelombang eksitasi $370 \mathrm{~nm}$ dan emisi $440 \mathrm{~nm}$.

Tabel 1. Komposisi larutan pada uji aktivitas antiglikasi.

\begin{tabular}{ccccc}
\hline Bahan yang digunakan & $\begin{array}{c}\text { Larutan A } \\
(\text { Kontrol glikasi }) \\
(\mu \mathrm{L})\end{array}$ & $\begin{array}{c}\text { Larutan B } \\
(\text { pengoreksi } \\
\text { kontrol })(\mu \mathrm{L})\end{array}$ & $\begin{array}{c}\text { Larutan C } \\
(\text { sampel }) \\
(\mu \mathrm{L})\end{array}$ & $\begin{array}{c}\text { Larutan D } \\
(\text { pengoreksi } \\
\text { sampel })(\mu \mathrm{L})\end{array}$ \\
\hline $\begin{array}{c}\text { Buffer fosfat 200 mM } \\
\mathrm{pH} 7.4\left(\mathrm{KH}_{2} \mathrm{PO}_{4} 0.2\right.\end{array}$ & 200 & & & \\
$\mathrm{M}+\mathrm{K}_{2} \mathrm{HPO}_{4} 0.2 \mathrm{M}$ & & 200 & 200 & 200 \\
dalam akuades $)$ & 80 & & & \\
BSA 20 mg/ml & 40 & - & 80 & 80 \\
Glukosa 235 mM & 40 & - & 40 & - \\
Fruktosa 235 mM & - & - & 80 & - \\
Ekstrak/aminoguanidin & & & & 80 \\
\hline
\end{tabular}




\section{Penentuan Aktivitas Penghambatan Tirosinase}

Penentuan aktivitas penghambatan enzim tirosinase mengacu pada (Batubara et al. 2015). Pada pengujian aktivitas penghambatan enzim tirosinase ini digunakan L-tirosina dan L-DOPA sebagai substrat dan asam kojat sebagai kontrol positif. Sampel dilarutkan dengan DMSO sebagai larutan stok. Variasi konsentrasi dibuat dengan melarutkan kolagen menggunakan buffer fosfat $\mathrm{pH}$ 6,5. Sebanyak $70 \mu \mathrm{L}$ larutan dimasukkan ke dalam pelat 96 sumur, kemudian ditambahkan $30 \mu \mathrm{L}$ enzim tirosinase (Sigma, 333 Unit mL-1 dalam larutan buffer fosfat), dan campuran diinkubasi selama 5 menit. Setelah itu, ditambahkan sebanyak $110 \mu \mathrm{L}$ substrat (L-tirosin $2 \mathrm{mM}$ ) kemudian diinkubasi pada suhu $37{ }^{\circ} \mathrm{C}$ selama 30 menit. Absorbans diukur pada panjang gelombang $492 \mathrm{~nm}$ menggunakan Spektrofotometer Microplate Reader.

\section{Analisis Data}

Data yang diperoleh dalam penelitian ini ditabulasi, kemudian dilakukan uji menggunakan metode analisis deskriptif dengan penilaian secara kualitatif maupun kuantitatif. Metode analisis deskriptif yang digunakan melalui penentuan gugus fungsi (FTIR) untuk menentukan kolagen terbaik dari pengaruh perendaman tiga variasi konsentrasi $\mathrm{NaOH}$. Pemilihan hasil terbaik didasarkan pada aktivitas antioksidan, antiglikasi, dan antitirosinase. Data yang diperoleh dari tiga kali ulangan dilakukan analisis menggunakan ANOVA pada selang kepercayaan 95\% dan dilanjutkan uji lanjut Duncan jika diperlukan.

\section{HASIL DAN PEMBAHASAN}

\section{Kandungan Proksimat Tulang Ayam}

Analisis proksimat dilakukan terhadap serbuk tulang ayam, berupa analisis kadar air, kadar lemak, dan kadar protein (Tabel 2).

Tabel 2. Kandungan proksimat sampel tulang ayam.

\begin{tabular}{c|ccc}
\hline Kandungan & Air & Lemak & Protein \\
\hline Kadar $(\%)$ & 6,93 & 15,23 & 51,73 \\
\hline
\end{tabular}

Penentuan kadar air suatu bahan perlu dilakukan untuk menghitung rendemen dalam satuan basis basah dan kering. Penentuan kadar air juga dapat digunakan untuk menentukan umur simpan sampel. Menurut Keputusan Menkes RI No. 661/MENKES/SK/VII/1994, nilai kadar air yang baik ialah kurang dari 10\%. Hal ini 
menunjukkan bahwa sampel yang digunakan dalam penelitian sudah sesuai dengan standar yang berlaku.

Sampel yang digunakan memiliki kadar protein lebih dari 50\%. Kadar protein pada sampel tulang tersebut menentukan jumlah kolagen yang terkandung dan memiliki potensi yang baik untuk dijadikan sebagai sumber kolagen. Kadar lemak pada sampel menunjukkan kandungan lemak yang relatif tinggi $(15,27 \%)$ dibandingkan dengan kadar lemak pada penelitian Putra et al. (2011) sebesar 1,68\%, sehingga perlu dilakukan praperlakuan untuk mendapatkan kolagen yang bebas dari lemak. Kadar lemak yang tinggi pada bahan akan mempengaruhi efektivitas kolagen dalam aplikasinya pada berbagai produk (Shon et al., 2011). Pra perlakuan untuk mengurangi kadar lemak dan bahan lainnya dilakukan dengan cara merendam serbuk tulang ayam menggunakan $\mathrm{NaOH}$. Perendaman ini menyebabkan reaksi penyabunan (saponifikasi) antara $\mathrm{Na}$ pada $\mathrm{NaOH}$ dengan lemak dari sampel sehingga lemak dapat berkurang (Yuhendri, 2017).

\section{Perolehan Kolagen}

Perolehan kolagen dari hasil perendaman menggunakan berbagai konsentrasi $\mathrm{NaOH}$ dan $\mathrm{CH}_{3} \mathrm{COOH}$ disajikan pada Tabel 3.

Tabel 3. Rendemen kolagen hasil isolasi dengan variasi $\mathrm{NaOH}$ dengan $\mathrm{CH}_{3} \mathrm{COOH} 1 \mathrm{M}$

\begin{tabular}{cc}
\hline Konsentrasi NaOH (M) & Rendemen Kolagen (\%) \\
\hline 0,05 & 10,42 \\
0,10 & 12,59 \\
0,20 & 10,94 \\
\hline
\end{tabular}

Pembuatan kolagen diawali dengan pra-perlakuan untuk menghilangkan protein nonkolagen pada sampel sehingga hanya protein kolagen yang larut dalam ekstraksi selanjutnya. Protein jaringan ikat merupakan protein yang lebih sulit diekstraksi apabila dibandingkan dengan protein lain. Oleh karena itu pada saat pra-perlakuan diperlukan larutan $\mathrm{NaOH}$ untuk memisahkan protein-protein nonkolagen. Kolagen biasanya tidak dapat larut dalam larutan alkali. Penggunaan $\mathrm{NaOH}$ biasa digunakan dalam proses praperlakuan ekstraksi kolagen karena mampu meminimalkan kehilangan kolagen secara signifikan apabila dibandingkan dengan larutan alkali lain (Liu et al., 2015).

Perlakuan dengan $\mathrm{NaOH}$ 0,10 M memberikan rendemen kolagen paling tinggi. Rendemen menunjukkan keefektifan proses ekstraksi. Perbedaan nilai rendemen pada kolagen yang dihasilkan dapat disebabkan oleh perbedaan metode ekstraksi yang 
digunakan, konsentrasi larutan yang digunakan untuk menghilangkan protein non kolagen, dan jenis bahan yang digunakan (Potaros et al., 2009).

Perendaman menggunakan $\mathrm{CH}_{3} \mathrm{COOH}$ mengakibatkan terputusnya ikatan hidrogen intramolekul yang merupakan penstabil struktur triple helix kolagen (Ahmad and Benjakul, 2010). Sampel yang digunakan dicuci dengan air untuk menetralkan pH. Larutan kolagen yang diperoleh kemudian dikeringkan dengan freezedryer sehingga didapatkan kolagen kering (Tabel 2).
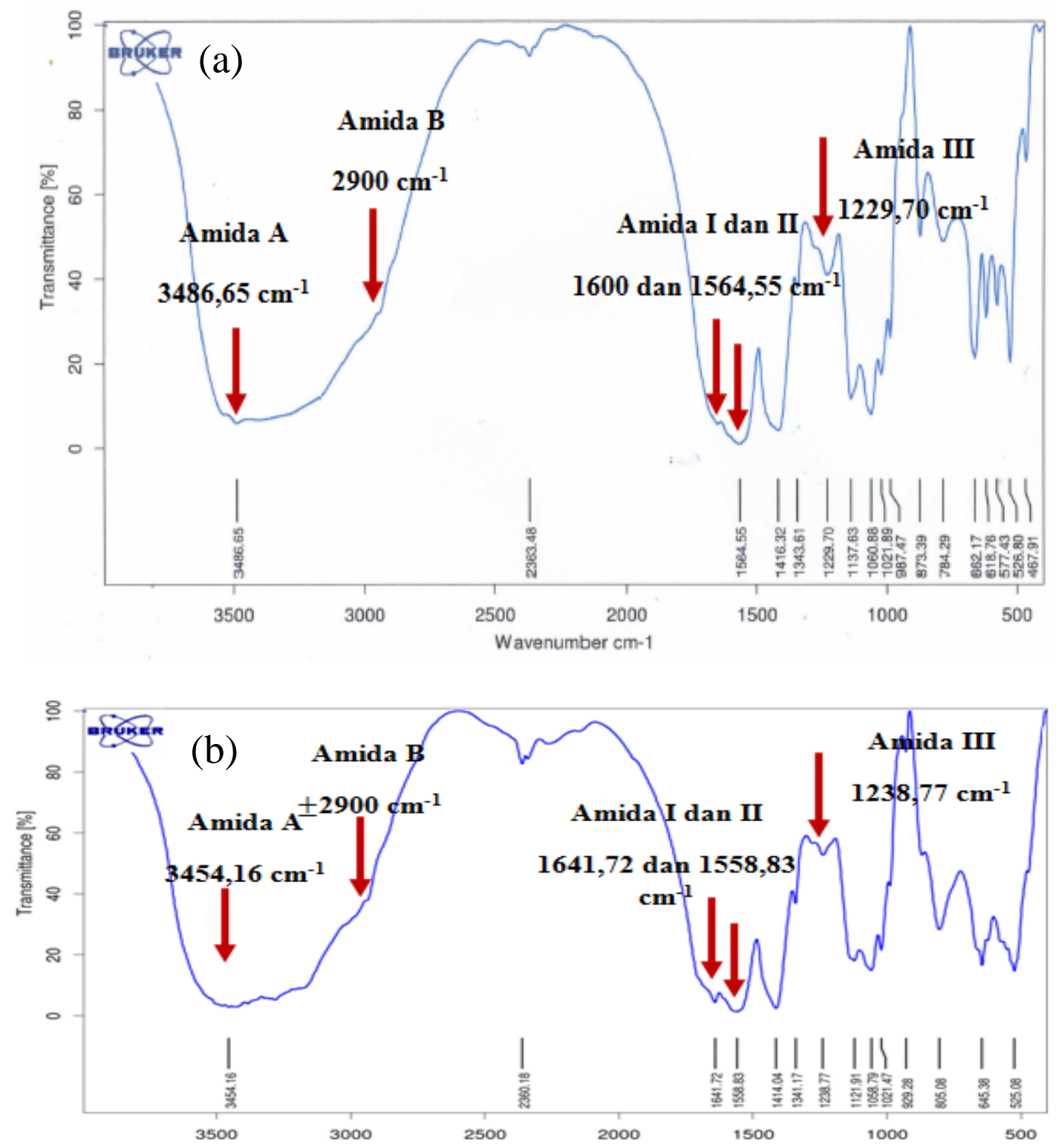

Gambar 1. Spektrum FTIR kolagen dengan perendaman $\mathrm{NaOH}$ (a) 0,05 and (b) $0,1 \mathrm{M}$

Kolagen yang dihasilkan kemudian dianalisis gugus fungsinya menggunakan FTIR, untuk memastikan kemurnian kolagen. Prinsip dari FTIR yaitu pengukuran panjang gelombang dan intensitas penyerapan radiasi inframerah oleh sampel. Penyerapan radiasi 
inframerah menimbulkan getaran yang dapat mengindikasikan kelompok peptida dan rantai sampingnya, sehingga memberikan informasi mengenai struktur protein (Kong and Yu, 2007). Kolagen tergolong dalam protein yang memiliki ikatan peptida. Keberadaan gugus amida merupakan gugus fungsi yang paling mudah dideteksi dalam FTIR (Sjahfirdi et al., 2012). Terdapat 9 jenis amida yang dapat dideteksi pada protein yaitu Amida A, B, dan Amida I-VII. Tiap jenis amida ini memberikan sinyal pada bilangan gelombang spesifi karena keberadaan gugus tertentu.
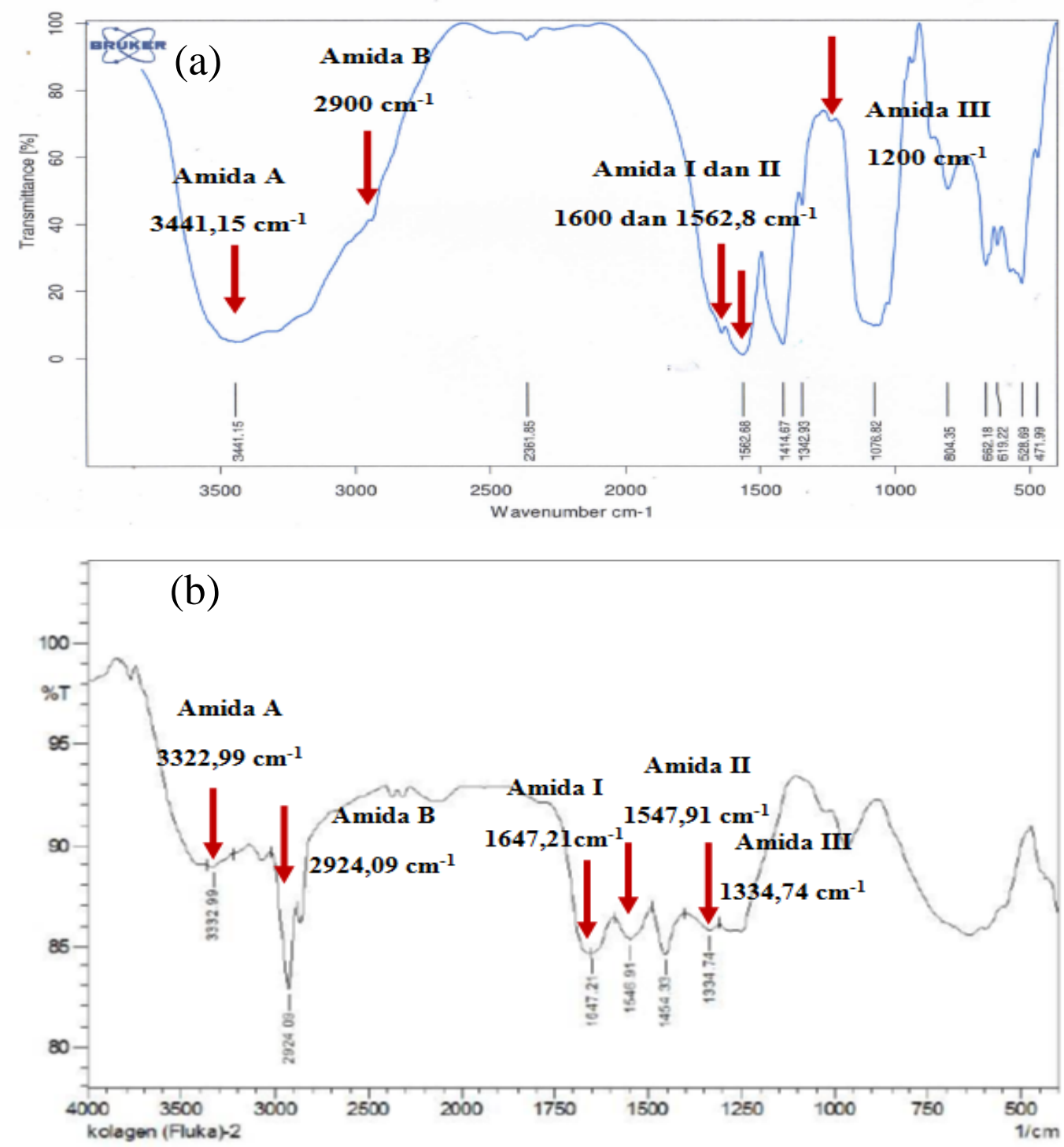

Gambar 2. Spektrum FTIR (a) kolagen dengan perendaman $\mathrm{NaOH} \mathrm{0,20} \mathrm{M} \mathrm{dan}$ (b) kolagen standar (Yuhendri, 2017).

Berdasarkan spektrum FTIR kolagen dari tulang ayam menunjukkan puncakpuncak serapan pada wilayah serapan amida yang meliputi amida $\mathrm{A}$, amida $\mathrm{B}$, amida $\mathrm{I}$, amida II, dan amida III yang merupakan gugus fungsi khas kolagen (Tabel 4 dan Gambar 1-2). Daerah amida A menunjukkan keberadaan gugus NH yang dekat dengan keberadaan 
ikatan hidrogen sehingga muncul pada bilangan gelombang $3300-3500 \mathrm{~cm}^{-1}$. Amida B menunjukkan keberadaan gugus $\mathrm{CH}$, sementara daerah amina I menunjukkan adanya gugus $\mathrm{C}=\mathrm{C}$ yang merupakan struktur sekunder protein, daerah amina II menunjukkan ikatan NH dan amida III menunjukkan adanya ikatan NH pada struktur heliks kolagen (Muyonga et al., 2004). Spektrum FTIR pada penggunaan konsentrasi $\mathrm{NaOH} \mathrm{0,10} \mathrm{M}$ menunjukkan gugus fungsi khas dari semua serapan amida yang paling terlihat pada wilayah serapan masing-masing amida, hanya pada amida B yang tidak jelas bilangan gelombangnya, namun masih menunjukkan puncak di wilayah serapannya.

Tabel 4. Karakteristik gugus fungsi kolagen hasil analisis FTIR Kolagen $\mathrm{NaOH}$.

\begin{tabular}{|c|c|c|c|c|c|}
\hline \multirow[t]{2}{*}{ Amida } & \multicolumn{3}{|c|}{$\begin{array}{c}\text { Bilangan gelombang }\left(\mathrm{cm}^{-1}\right) \\
\text { kolagen } \mathrm{NaOH}\end{array}$} & \multirow{2}{*}{$\begin{array}{l}\text { Wilayah } \\
\text { serapan } \\
\left(\mathrm{cm}^{-1}\right)^{*}\end{array}$} & \multirow[t]{2}{*}{ Keterangan* } \\
\hline & $0,05 \mathrm{M}$ & $0,10 \mathrm{M}$ & $0,20 \mathrm{M}$ & & \\
\hline A & 3486 & 3454 & 3441 & $3300-3500$ & $\begin{array}{c}\text { Vibrasi stretching } \\
\mathrm{NH}\end{array}$ \\
\hline B & Tidak Jelas & Tidak Jelas & Tidak Jelas & $2915-2935$ & $\begin{array}{c}\text { Asimetrikal } \\
\text { stretching } \mathrm{CH}_{2}\end{array}$ \\
\hline I & Tidak Jelas & 1641 & Tidak Jelas & $1600-1690$ & $\begin{array}{c}\text { Vibrasi stretching } \\
\mathrm{C}=\mathrm{O}\end{array}$ \\
\hline II & 1564 & 1558 & 1562 & $1480-1575$ & $\begin{array}{l}\text { CH stretching, } \\
\text { NH bending }\end{array}$ \\
\hline III & 1229 & 1238 & Tidak Jelas & $1229-1301$ & $\begin{array}{l}\mathrm{CH} \text { stretching, } \\
\mathrm{NH} \text { bending }\end{array}$ \\
\hline
\end{tabular}

*Sumber: Kong and Yu (2007)

\section{Ukuran Partikel Kolagen}

Kolagen yang diperoleh ditentukan ukuran partikelnya menggunakan PSA. Ukuran partikel yang diperoleh berkisar 1102 hingga 2344 nm yang menunjukkan ukurannya belum nano (Tabel 5). Menurut Mohanraj and Chen (2006), ukuran partikel nano yaitu 10$1000 \mathrm{~nm}$. Oleh karena itu, perlu dilakukan optimasi lebih lanjut terhadap waktu dan kecepatan pengadukan untuk menghasilkan ukuran kolagen yang nano partikel. Kolagen yang dihasilkan menggunakan $\mathrm{NaOH} 0,10 \mathrm{M}$ merupakan kolagen yang lebih baik berdasarkan data FTIR dan memiliki ukuran partikel paling besar berdasarkan hasil analisis PSA. Untuk meningkatkan kemampuannya diserap oleh kulit perlu diperkecil ukuran partikelnya melalui proses pengadukan. 
Tabel 5. Ukuran Partikel serta Aktivitas Antioksidan dan Antiglikasi Kolagen.

\begin{tabular}{lccc}
\hline Perlakuan Kolagen & $\begin{array}{c}\text { Ukuran Partikel } \\
(\mathrm{nm})\end{array}$ & $\begin{array}{c}\text { Penghambatan DPPH } \\
(\%)\end{array}$ & $\begin{array}{c}\text { Penghambatan glikasi } \\
(\%)\end{array}$ \\
\hline $\mathrm{NaOH} 0,05 \mathrm{M}$ & 1102 & $10,42^{\mathrm{b}}$ & $47,85^{\mathrm{a}}$ \\
$\mathrm{NaOH} 0,10 \mathrm{M}$ & 2344 & $7,36^{\mathrm{a}}$ & $61,06^{\mathrm{b}}$ \\
$\mathrm{NaOH} 0,20 \mathrm{M}$ & 1871 & $13,72^{\mathrm{b}}$ & $60,47^{\mathrm{b}}$ \\
\hline $\mathrm{NaOH} 0,10 \mathrm{M} 6 \mathrm{jam}$ & 1342 & $24,70^{\mathrm{c}}$ & $(-)$ \\
$\mathrm{NaOH} 0,10 \mathrm{M} 8 \mathrm{jam}$ & 1798 & $10,05^{\mathrm{b}}$ & $(-)$ \\
\hline Keterangan : & &
\end{tabular}

Ukuran partikel kolagen setelah diaduk menjadi lebih kecil dua kali lipat terutama saat diaduk 6 jam sementara yang diaduk 8 jam ukurannya kembali menjadi besar akibat proses koagulasi. Oleh karena itu, pengadukan selama 6 jam cukup untuk memperkecil ukuran kolagen, namun belum mencapai ukuran nano. Menurut Mohanraj and Chen (2006), karena ukuran nano menurutnya adalah saat ukuran partikelnya 10-1000 nm. Untuk memperkecil ukuran partikel sebaiknya tidak melalui proses mekanik seperti pengadukan, namun dapat dilakukan melalui proses hidrolisis.

\section{Aktivitas Antioksidan, Antiglikasi, dan Inhibitor Tirosinase}

Perlakuan kolagen $\mathrm{NaOH}$ 0,10 $\mathrm{M}$ dibandingkan perlakuan konsentrasi $\mathrm{NaOH}$ lainnya menghasilkan ukuran paling besar, namun aktivitas antiglikasinya paling tinggi dan aktivitas antioksidannya paling rendah. Pengecilan ukuran kolagen yang dilakukan dengan pengadukan 1000 rpm dengan 6 dan 8 jam menghasilkan kolagen dengan ukuran yang lebih kecil dan aktivitas antioksidannya semakin tinggi. Persen penghambatan DPPH kolagen yang dihasilkan mirip dengan kolagen komersial yaitu $\mathrm{IC}_{50}$-nya lebih besar dari 1000 ppm (Shita, 2018). Aktivitas antiglikasi pada kolagen $\mathrm{NaOH}$ 0,10 M dengan pengadukan 6 dan 8 jam tidak dapat ditentukan karena aktivitas yang terlalu tinggi, sehingga perlu dilakukan pengujian pada konsentrasi yang lebih tinggi, sedangkan pada konsentrasi yang lebih tinggi lagi reaksi protein dan glukosa akan lebih banyak sehingga makin sulit untuk dideteksi menggunakan fluorimetri. Aktivitas antiglikasi yang dihasilkan lebih tinggi apabila dibandingkan dengan kolagen yang didapatkan pada penelitian Shita (2018) yaitu sebesar 17,74\% pada konsentrasi 3000 ppm 
Kolagen yang didapatkan diharapkan akan digunakan untuk produk kosmetik yang digunakan untuk kulit. Penghambatan aktivitas tirosinase dapat mengurangi produksi melanin berlebih yang menyebabkan warna hitam pada kulit. Aktivitas penghambatan tirosinase pada konsentrasi 1000 ppm disajikan pada Tabel 6.

Tabel 6. Aktivitas Antitirosinase Kolagen pada 1000 ppm.

\begin{tabular}{ccc}
\hline \multirow{2}{*}{ Kolagen } & \multicolumn{2}{c}{ Penghambatan tirosinase dengan substrat $(\%)$} \\
\cline { 2 - 3 } & L-tirosina & L-DOPA \\
\hline $\mathrm{NaOH} \mathrm{0,10} \mathrm{M} \mathrm{6} \mathrm{jam}$ & $9,17^{\mathrm{a}}$ & $26,77^{\mathrm{b}}$ \\
$\mathrm{NaOH} \mathrm{0,10} \mathrm{M} \mathrm{8} \mathrm{jam}$ & $7,95^{\mathrm{a}}$ & $2,72^{\mathrm{a}}$ \\
\hline
\end{tabular}

Keterangan: $\mathrm{IC}_{50}$ asam kojat: 8,90 ppm, Huruf dibelakang angka yang sama pada kolom yang sama menunjukkan tidak ada perbedaan yang signifikan pada $\alpha=0,05$

Aktivitas penghambatan enzim tirosinase menggunakan substrat L-tirosina dan LDOPA menunjukkan bahwa pengadukan selama 6 jam aktivitas penghambatan enzim tirosinase yang lebih besar daripada pengadukan 8 jam. Hal ini menunjukkan aplikasi pembuatan kolagen untuk kosmetika anti aging cukup dengan perendaman pada $\mathrm{NaOH}$ 0,10 M, perendaman dengan asam asetat $1 \mathrm{M}$, dan pengadukan pada $1000 \mathrm{rpm}$ selama 6 jam. Pada penelitian Shita (2018), kolagen komersial tidak menunjukkan aktivitas penghambatan enzim tirosinase saat pengujian pada 1000 ppm dan aktivitas penghambatan enzim tirosinase hidrolisat kolagen komersial pada penelitiannya tidak lebih baik dibandingkan dengan aktivitas dari kolagen yang diperoleh pada penelitian ini.

\section{KESIMPULAN}

Kolagan telah diisolasi dari limbah tulang ayam dengan kondisi optimum, yaitu perendaman tulang ayam pada konsentrasi $\mathrm{NaOH} 0,10 \mathrm{M}$, dilanjutkan perendaman dengan asam asetat $1 \mathrm{M}$, dan diteruskan dengan pengadukan menggunakan stirrer kecepatan 1000 rpm selama 6 jam. Kondisi optimum ini memberikan rendemen paling tinggi dan aktivitas anti aging terbaik berdasarkan aktivitas antioksidan, antiglikasi, dan antitirosinase. Ukuran partikel kolagen pada konsentrasi $\mathrm{NaOH} 0,10$ M yang semakin kecil menyebabkan aktivitasnya semakin tinggi.

\section{UCAPAN TERIMAKASIH}

Penulis mengucapkan terima kasih kepada Direktorat Pendidikan Tinggi, Kemenristek Dikti yang telah menghibahkan dana untuk pelaksanaan program PKM-PE 
ini. Selain itu, tim juga mengucapkan terima kasih kepada PKM Center, Direktorat Kemahasiswaan IPB, dan seluruh pihak yang terlibat dalam kelancaran penelitian ini.

\section{REFERENSI}

[AOAC] The Association of Official Analytical Chemist. 2012. Official Methods of Analysis. Ed ke-19.Washington DC (US): Association of Official Analytical Chemist.

[MENKES] Menteri Kesehatan Republik Indonesia. Keputusan Menteri Kesehatan Republik Indonesia. No.: 661/MENKES/SK/VII/1994. Persyaratan obat tradisional.

[SNI] Standar Nasional Indonesia. 1992. SNI 01-2891-1992. Cara uji makanan dan minuman. Jakarta (ID): Dewan Standar Nasional.

Ahmad, M. and Benjakul, S. 2010. Extraction and characterization of pepsin solubillised collagen from the skin of unicorn leatherjacket (Aluterus monocerous). Food Chemistry 120, 817-824

Batubara, I., Mitsunaga, T. and Ohashi. H. 2009. Screening antiacne potency of Indonesian medicinal plants: antibacterial, lipase inhibition, and antioxidant activities. Journal of Wood Science 55, 230-235.

Batubara, I., Julita, I., Darusman, L.K., Muddathir, A.M. and Mitsunaga, T. 2015. Flower bracts of temulawak (Curcuma xanthorrhiza) for skin care: anti-acne and whitening agents. Procedia Chemistry. 14, 216-224.

Farage, M.A., Miller, K.W., and Maibach, H.I. 2016. Degenerative Change in Skin. Textbook in Aging Skin 15-30

Hoet, P.H.M., Bruske, H.I., and Salata, O.V. 2004. Nanoparticles known and unknown health risks. Journal Nanotechnology 2(12), 1-5.

Kong, J., and Yu, S. 2007. Fourier transform infrared spectroscopic analysis of protein secondary structures. Acta Biochim Biophys Sinica 39(8), 549-559.

Liu, D., Wei, G., Li, T., Hua, J., Lu, J., Regenstein, J.M., and Zhou, P. 2015. Effects of alkaline preatreatment and acid extraction onditions on the acid sluble collagen from grass carp (Ctenopharyngodon idella) skin. Food Chemistry 172, 836-843.

Mohanraj, V.J., and Chen, Y. 2006. Nanoparticles-A Review. Tropical Journal of Pharmaceutical Research 5(1): 561-573.

Muyonga, J.H., Cole, C.G.B., and Duodu, K.G. 2004. Fourier Transform infrared (FTIR) spectroscopic study of acid soluble collagen and gelatin from skins and bones of young and adult nile perch (Latex niloticus). Food Chemistry 86, 325-332

Nagai, R., Jinno, M., Ichihashi, M., Koyama, H., Yamamoto, Y., and Yonei Y. 2012. Advanced Glycation End Poducts and Their Receptors as Risk Factors for Aging. Anti-Aging Medicine 9(4), 108-113

Potaros, T., Raksakulthai, N., Runglerdkreangkrai, J., and Worawattanamateekul, W. 2009. Characteristics of collagen from nile tilapia (Oreochromis niloticus) skin isolated by two different methods. Kasetsart Journal 43, 584-593. 
Povichit, N., Phrutivorapongkul, A., Suttaji, M., Chaiyasut, C., and Leelapornpisid, P. 2010. Antiglycation and antioxidant activities of oxyresveratol extracted from the heartwood of Artocaprus lakoocha Roxb. Maejo International Journal of Science and Technology 23(4), 454-461.

Putra, A. B., Sahubawa, L., and Ekantari, N. 2011. Ekstraksi dan karakterisasi kolagen dari kulit ikan nila hitam (Oreochromis niloticus). Jurnal pascapanen dan bioteknologi kelautan dan perikanan 8(2), 171-180.

Shita, F. 2018. Hidrolisat kolagen kulit ikan tuna sirip kuning (thunnus albacares) sebagai anti penuaan. Disertasi. Institut Pertanian Bogor: Bogor.

Silva, T.H., Moreira-Silva, Marques, A.L.P., Domingues, A., Brayo, I., and Reis, L. 2014. Marine origin collagens and its potential applications. Marine Drugs 12(12), 58815901.

Sjahfirdi, L., Mayangsari, and Nasikin, M. 2012. Protein identification using Fourier Tranform Infrared (FTIR). International Journal of Recent Research and Applied Studies 10(3), 418-421

Shon, J., Ju-Hyun, E., Hwang, S.J., and Jong-Bang, E. 2011. Effect of Processing condition on functional properties of collagen powder from Skate (Raja kenojei) skins. The Journal of Food Science Biotechnology 20(1), 99-106

Yuhendri, V. M. 2017. Karakterisasi dan Aktivitas Penghambat Tirosinase oleh Kolagen dari Teripang. Skripsi. Institut Pertanian Bogor: Bogor 